\title{
Monitoring of Construction at Site 41BX1199, Government Canyon State Natural Area, Bexar County, Texas
}

Jason D. Weston

Follow this and additional works at: https://scholarworks.sfasu.edu/ita

Part of the American Material Culture Commons, Archaeological Anthropology Commons, Environmental Studies Commons, Other American Studies Commons, Other Arts and Humanities Commons, Other History of Art, Architecture, and Archaeology Commons, and the United States History Commons

Tell us how this article helped you.

This Article is brought to you for free and open access by the Center for Regional Heritage Research at SFA ScholarWorks. It has been accepted for inclusion in Index of Texas Archaeology: Open Access Gray Literature from the Lone Star State by an authorized editor of SFA ScholarWorks. For more information, please contact cdsscholarworks@sfasu.edu. 
Monitoring of Construction at Site 41BX1199, Government Canyon State Natural Area, Bexar County, Texas

\section{Creative Commons License}

\section{(c) (1) \&}

This work is licensed under a Creative Commons Attribution-NonCommercial 4.0 International License 


\title{
Monitoring of Construction at Site 41BX1199, Government Canyon State Natural Area, Bexar County, Texas
}

\author{
by \\ Jason D. Weston \\ Principal Investigators \\ Russell D. Greaves and Steve A. Tomka
}

Texas Antiquities Committee Permit No. 2582

Prepared for:

Texas Parks and Wildlife Department 4200 Smith School Road

Austin, Texas
Prepared by:

Center for Archaeological Research The University of Texas at San Antonio Letter Report, No. 149

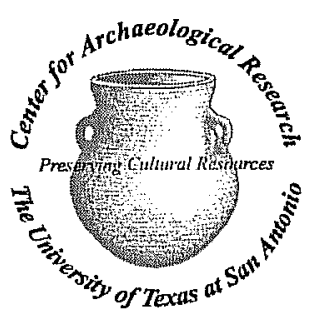

${ }^{\circ} 2003$ 


\section{Abstract:}

In February 2002, archaeologists from the Center for Archaeological Research at The University of Texas at San Antonio monitore the construction of roads and parking lots and the clearing of land on site 41BX1199 in Government Canyon State Natural Area. These roads and parking lots were being built to provide/facilitate access to picnic and tent camping areas planned for when the state natural area becomes a state park. Archaeological monitoring identified no significant archaeological deposits and confirmed the original assessment of the site as having no research potential. The construction activities did not impact any significant intact cultural deposits on site 41BX1199. 


\section{Table of Contents:}

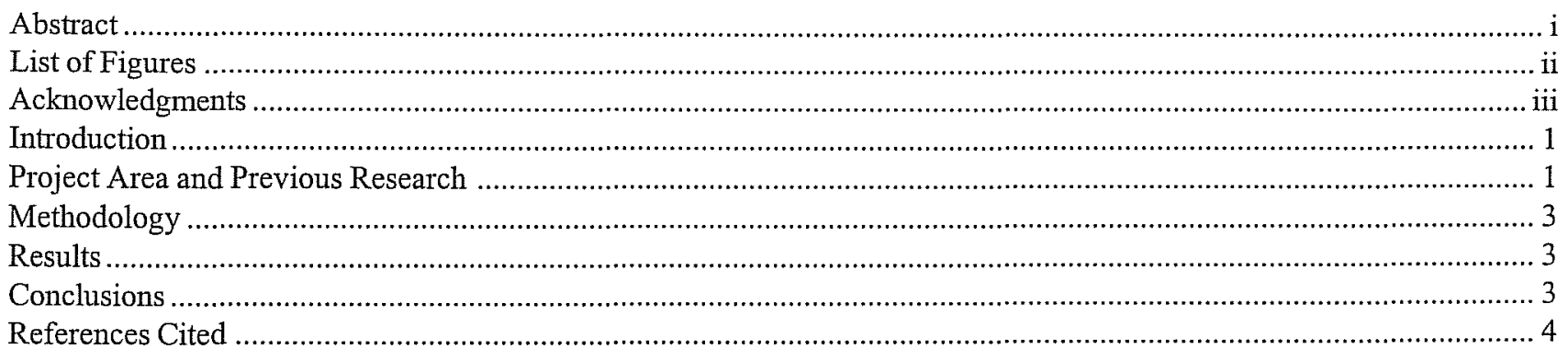

\section{List of Figures:}

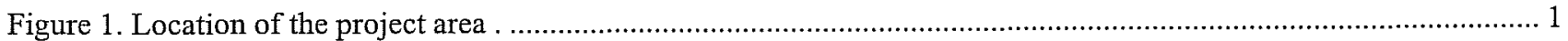

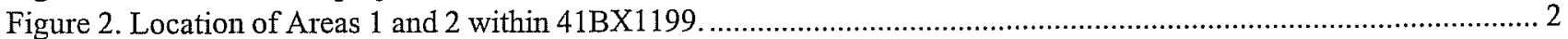




\section{Acknowledgments:}

The author would like to thank Deirdre E. Hisler and the Texas Parks and Wildlife Department Staff at Government Canyon State Natural Area for their hospitality and assistance. Thanks also to George Kegley, the Cultural Resource Coordinator for Region 5. The author would like to also thank the following Center for Archaeological Research (CAR) staff involved in the project: Dr. Russell Greaves and Dr. Steve Tomka, principal investigators; Ruth Mathews and all members of the CAR Government Canyon survey crew involved in the monitoring of the construction at 41BX1199; Rick Young for drafting the figures; and Donna Edmondson and Johanna Hunziker for editing and formatting this report. 


\section{Introduction}

In February of 2002, archaeologists from the Center for Archaeological Research (CAR) at The University of Texas at San Antonio monitored the clearing of brush and the cutting of a roadbed into the soils of site 41BX1199 in Government Canyon State Natural Area in northwest Bexar County (Figure 1). This work was done for the Texas Parks and Wildlife Department (TPWD) under Texas Antiquities Permit No. 2582.

\section{Project Area and Previous Research}

Site 41BX1199, approximately 68 acres in size, was originally documented and shovel tested by TPWD archaeologists in 1996 (McNatt et al. 2000). Plans to open Government Canyon State Natural Area to public access necessitated the improvement of existing trail systems and the construction of new support facilities. Two facilities are currently under construction on the relatively flat southern portion of the natural area that encompasses 41BX1199.

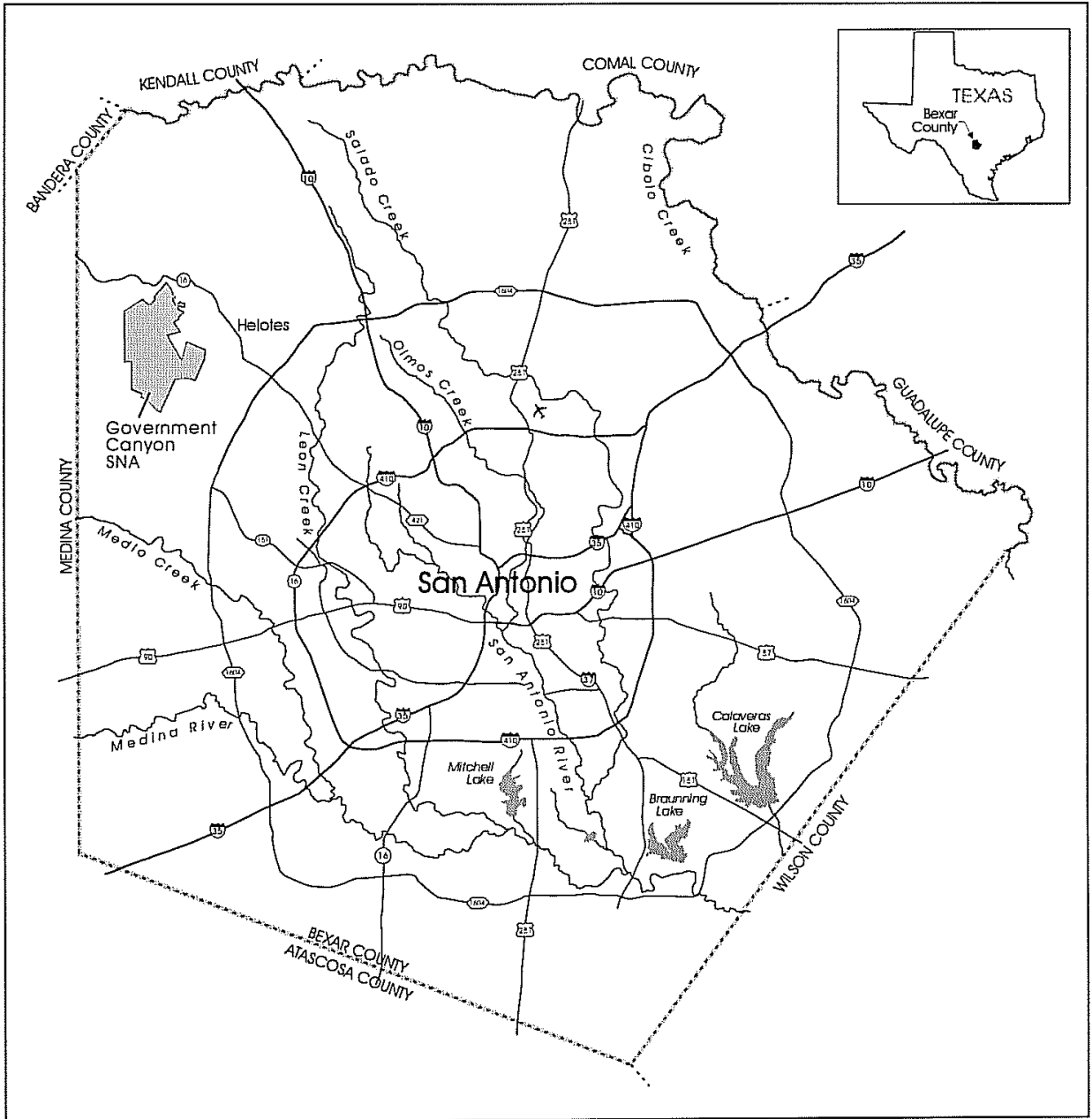

Figure 1. Location of the project area . 
This page has been

redacted because it

contains restricted

information. 


\section{Methodology}

The heavy vegetation of oak, juniper, whitebrush, prickly pear cactus and a variety of other thorny plants was cleared using a bulldozer, backhoe, and bobcat. The primary earthmover for setting the roadbed and parking lots was a scraper. An archaeologist from CAR monitored this activity from in front of and to the side of the machinery where the disturbance of the soils could be seen and any artifacts or features present could be spotted. A hard hat and safety vest were worn at all times.

\section{Results}

In Area 1, the picnic area, work involved monitoring of the construction of a road into the site, parking lot construction, and brush clearing for the picnic area and restrooms. In Area 2 , the camping area, work involved the monitoring of construction of small parking spaces, restrooms, and the clearing of land for tent sites, as well as the creation of a road to that area (Figure 2). Monitoring at both areas revealed only prehistoric cultural materials. The amount of cultural material seen during monitoring was very small. The artifacts only observed consisted of six scattered, unmodified lithic debitage, one early stage biface, and a sparse scatter of burned rock. No artifacts were collected. Considering the size of the affected area, this demonstrates an extremely low artifact density. No diagnostic artifacts were found and no features were noted.

During the clearing and scraping for the large parking lot in Area 1, several rock concentrations were noted. These piles of unmodified limestone were carefully inspected under the suspicion that they were potential burial cairns. No burials were present and close examination of the structure of the concentrations indicated that the rock piles were the result of previous bulldozer work, possibly from earlier ranch road maintenance or field clearing prior to plowing.

\section{Conclusions}

Monitoring of construction work at 41BX1199 noted six pieces of unmodified debitage, a single unfinished biface, and minor amounts of burned rock. These finds come from Areas 1 and 2 and the roads connecting them. This low density of recovery is consistent with the findings of the testing performed at the site (see Weston 2001:12-13). No significant archaeological deposits or culturally/temporally diagnostic artifacts were noted during monitoring. None of the cultural materials noted during monitoring change the assessment that the site has a very low research potential. The rock concentrations, while man-made, were not graves and have no archaeological interest. The results of the present monitoring efforts do not alter the recommendations made in the testing report (Weston 2001:13). As stated in the testing report, the long-term equestrian trail traffic and pedestrian traffic on paths to the campsites will occasionally expose artifacts. It is recommended that these areas be periodically examined for exposed artifacts. The few formal artifacts that may come to light as a result of this impact may be collected, assigned to general surface provenience on site, and used in park-related exhibits and public outreach presentations offered to park visitors. Such exhibits are optional and at the discretion of the TPWD staff at Government Canyon State Natural Area. 


\section{References Cited}

McNatt, L., C. Beceiro, M. D. Freeman, M. Howard, S. A. Tomka, P. Schuchert, and C. G. Ward

2000 Archaeological Survey and History of Government Canyon State Natural Area, Bexar County, Texas. Texas Parks and Wildlife, Cultural Resources Program, Austin.

Weston, J. D.

2001 Archaeological Testing of Site 41BX1199, Government Canyon State Natural Area, Bexar County, Texas. Archaeological Survey Report, No. 323. Center for Archaeological Research, The University of Texas at San Antonio. 